TTR

Traduction, terminologie, re?daction

\title{
Creole... English: West Indian Writing as Translation
}

\section{Joanne Akai}

Volume 10, numéro 1, 1er semestre 1997

Langues, traduction et post-colonialisme

Languages, Translation and Post-Colonialism

URI : https://id.erudit.org/iderudit/037283ar

DOI : https://doi.org/10.7202/037283ar

Aller au sommaire du numéro

\section{Éditeur(s)}

Association canadienne de traductologie

ISSN

0835-8443 (imprimé)

1708-2188 (numérique)

Découvrir la revue

Citer cet article

Akai, J. (1997). Creole... English: West Indian Writing as Translation. TTR, 10(1), 165-195. https://doi.org/10.7202/037283ar

\section{Résumé de l'article}

Créole... anglais : l'écriture caribéenne comme traduction — Cet article examine les jeux de langues et langages dans la littérature indo-caribéenne de langue anglaise. Les écrivains caribéens sont créoles, dans tous les sens du terme : ils sont nés dans les (anciennes) colonies britanniques; ils appartiennent à une culture métisse; et ils parlent une langue métisse. Ils oeuvrent dans un continuum linguistique et culturel créole; ils possèdent plusieurs variétés linguistiques (du créole à l'anglais standard) et revendiquent l'appartenance à plusieurs bases culturelles (de la culture orale "primitive" créole à la culture urbaine "anglicisée"). Toutefois, les écrivains indo-caribéens ont accès non seulement au continuum linguistique et culturel créole, mais aussi aux traditions culturelles, linguistiques et religieuses pré-coloniales de leurs ancêtres venus des Indes au XIXe siècle. Mais, si le créole est la langue maternelle des gens des Caraïbes, l'anglais n'en demeure pas moins la seule langue qu'ils lisent et qu'ils écrivent. La littérature caribéenne de langue anglaise constitue un tissu soigneusement mé-tissé du créole et de l'anglais : une écriture métisse née de la traduction de l'expérience créole en anglais; de la culture orale créole en anglais écrit; et de la langue créole en langue anglaise. En fait, la littérature caribéenne de langue anglaise peut être considérée comme une auto-traduction, dont l'auteur-traducteur valide l'aspect métissé, un extrait authentique qui rend l'essence de l'écrivain caribéen et de sa langue-culture caribéenne.
Tous droits réservés (C TTR: traduction, terminologie, rédaction — Les auteurs, 1997
Ce document est protégé par la loi sur le droit d'auteur. L'utilisation des services d'Érudit (y compris la reproduction) est assujettie à sa politique d'utilisation que vous pouvez consulter en ligne.

https://apropos.erudit.org/fr/usagers/politique-dutilisation/ 


\title{
Creole... English : West Indian Writing as Translation
}

\author{
Joanne Akai
}

\section{Introduction}

The West Indies - and by this I mean the English-speaking islands (former British colonies) in the Caribbean, and the mainland nation, Guyana, on the South American coast - began with an almost unprecedented act of genocide : the Amerindian peoples, Caribs and Arawaks, were virtually exterminated by 16 th-century European invaders, then replaced by African slaves transported to the region to work on sugar plantations, which changed hands as often as Europe went to war. The West Indies is probably the most fought-over region in colonial history. It is certainly the most ethnically diverse region in the world today, its entire population having been dislocated from Africa, India, China, Madeira or the Azores in the name of colonization, or displaced as refugees from Europe and the Middle East. West Indian peoples, no matter what their origins, share the common experience of imperialism, colonialism, subjugation, alienation, dependency, maldevelopment, marginalization, and the cultural trappings of a region which has suffered the most violent and destructive effects of colonization.

Most of the research done on the West Indies has tended to focus on the history and culture of Black West Indians. Caribbean Indians, i.e. West Indians of East Indian descent, are usually relegated to a footnote. The year 1998 will mark the 160th anniversary of East Indian indentured 
immigration to the Caribbean. East Indian immigrants entered the region at the lowest end of the social scale, but they have made an enormous contribution to the making of the West Indies. Today they constitute fragile majorities in the republics of Trinidad and Guyana (as well as in Dutch-speaking Surinam), former British colonies that received the bulk of East Indian indentured labourers in the 19th century. This paper aims at describing the complex cultural and linguistic background of the IndoCaribbean writer, and looks at the use of language(s) in Indo-Caribbean writings. Its ultimate goal is to show that West Indian writing is translation, or more specifically, self-translation.

\section{West Indian Culture : A Hybrid Culture}

The culture that drew everybody to the West Indies was that of Sugar. When slavery was abolished in the British West Indies (hereafter BWI) in 1834, sugar planters in British Guyana, Trinidad and Jamaica needed immigrant labour to supplement the now expensive, hostile and diminishing free-slave workforce. They found an inexhaustible reservoir in Asia. Between 1838 and 1917 the Indian subcontinent became the main supplier of immigrant labour to the sugar plantations in the West Indies. Recruits - for the labourers were supposedly "recruited" by an agent familiar with the structure of Indian society - came mainly from the agricultural areas of the northern provinces of Agra and Oudh (modernday Uttar Pradesh), Bihar and Bengal, with smaller numbers from the Madras Presidency in the south. The Indian immigrants brought with them few belongings, but a heavy cultural, religious and linguistic baggage. While some were repatriated at the end of their five-year indenture, the majority remained in the colonies.

Indenture was basically a system of exploitation and control. The early Indian indentured labourers simply replaced the African slaves on the plantations, and creolization - "indoctrination into the social customs and conventions, linguistic and cultural practices that had emerged out of contact between African slaves and European masters within a Caribbean plantation context" (Birbalsingh, 1993, p. viii) - began on the sugar plantations. Plantation life shielded the Indians from urban, predominantly 
African, Creole ${ }^{1}$ culture, but indoctrinated them into the cultural, spiritual and linguistic practices of the free-slaves who still worked in the cane-fields, as well as into colonial culture, British customs and mannerisms, and creolized English. In addition, the steady inflow of indentured Indian workers created a link with village-India and contributed to the preservation of Indian language(s), culture, customs and religious traditions.

Insidious colonization and anglicization began in the schoolrooms of the colonies. Public education, under the responsibility of Christian missions, was made available in the BWI as of 1835 , and this opened the door to other immigrant cultures, as well as to Christianity. By the end of indenture in 1917, the cultural dynamics in British Guyana and Trinidad were already multidirectional, but the Indians were absorbing more Creole culture than they were spreading Indian culture, probably because they remained attached to the land, their families and communities. With Independence, a new Caribbean culture emerged, but the Indo-Caribbean communities retained much of their Indian-ness, and forged a hybrid culture within the diverse ethnic elements and particular socio-political climate of their societies. Today, East Indians still dominate the agriculture sector and the rural areas, with small, but powerful, communities in the urban centres.

\section{The West Indian Language Situation : A Creole Continuum}

The "imperialist project of ideological control in its programme of strategic instruction in the name of Education" (Itwaru, 1996, p. 3) had one basic aim : producing loyal British subjects who would serve and further the interests of the Empire in the West Indies. English was the sole medium for teaching literacy, as well as of general instruction. It was in the schoolrooms that Creole-speaking children learned to read and write English, so that when some British Lord came on a visit to the

'The term "creole" generally refers to a person born in the colonies, as distinguished from a person bon in his/her home country; its core meaning is a mixture of European and non-European (usually African) elements originating in a Caribbean environment. 
colonies in the 1950 s, he was amazed and delighted that the local schoolchildren "could read and write and spell... but can't pronounce at all", or so the calypso goes. The introduction of English literature in the colonial education curriculum constituted another phase of colonization, of servitude to the Empire : now the dominated Creoles were persuaded to identify with their English dominator's definition of themselves. It was in these "schools of self-negation" that Creole children were graded, standardized and formed into secondary British subjects.

When the colonies obtained political independence from Britain (in the 1960s), English remained the sole official language of the countries of the new Commonwealth Caribbean : the diglossia, "involving, on the one hand, Creole as the language of everyday, informal interaction for the mass of the population, and English as the written, public-formal and official language, on the other, continued" (Devonish, 1986, p. 24). The education system inherited from the colonial power also continued, the assumption being that those whe entered the education system were in fact native speakers of English; English-lexicon Creole being no more than a form of "broken English" to be corrected. In the post-colonial movement, Creole was viewed as simply another of the "unfortunate by-products of colonialism". Creole was never valorized in the West Indies, and while it is still stigmatized and denied by the very communities in which it is spoken, there is widening recognition within official circles, thanks to the work of Caribbean linguists over the past 30 years, that Creole-speaking children come into the education system with a linguistically valid language variety.

English is still the official language of the Commonwealth Caribbean countries, but Creole is the mother-tongue of most, if not all West Indians. However, most middle- and upper-class West Indians, educated under the British education system that promoted literacy in English and identification with things British, claim not to be speaking Creole even though there are some linguistic differences ${ }^{2}$ between their

${ }^{2}$ E.g., the phonology: dem = them, tong = town; the lexicon: faisti = cheeky, jiga = sandfly; the syntax: De boys dem coming $=$ The boys (and their friends) are coming. 
West Indian English (WIE) and Standard English (SE). They prefer to think of Creole as being the basilectal ${ }^{3}$ variety furthest away from $\mathrm{SE}$, used mainly by country folks and market vendors. But the language situation in the English-speaking Caribbean is not a clear-cut bilingual or diglossic one, but rather a "Creole continuum" consisting of "postcreole speech communities, i.e., communities in which Creole is in the process of merging with the standard" (DeCamp, 1971, p. 349).

A Creole continuum results from the process of decreolization that occurs wherever a Creole language is in direct contact with its associated superstrate language. It refers to a "situation where a continuum of intermediate varieties develops between Creole and standard poles, as Creole speakers experience increased motivation and opportunity to modify their speech in the direction of the standard language" (Rickford, 1987, p. 2). In a Creole continuum then, there is no sharp distinction between the Creole and the standard; instead there is a continuous range of "overlapping, partly conflicting, intersecting and partly integrating systems and sub-systems, all in a state of flux" (D'Costa, 1983, p. 253), between the basilect and the acrolect that merges into the standiard language. In the Caribbean, the basilect is mainly prevalent in the rural areas, mesolectal varieties predominate in the urban areas, and the acrolect is associated with a small elite minority in the cities. The following diagram schematizes a Creole continuum : the circles represent the stages of decreolization - from the basilect through the intermediate varieties of the mesolect to the acrolect or WIE; the oval represents SE, the superstrate language.

${ }^{3}$ In creole linguistics, "basilect" refers to the basic variety of Creole, "acrolect" refers to the variety closest to the standard language; and "mesolect" to the intermediate varieties developed between the basilect and the acrolect, as the language changes over time. 


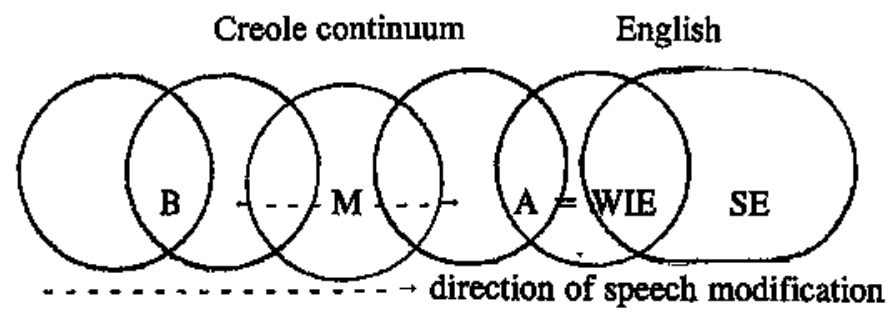

Figure 1 : The Creole continuum

Since immigration and settlement patterns differ, individualized creoles have evolved in each country. They are nonetheless mutually intelligible, and in fact, DeCamp could have been describing any Caribbean language community when he wrote :

Nearly all speakers of English in Jamaica could be arranged in a sort of linguistic continuum, ranging from the speech of the most backward peasant or labourer all the way to that of the well-educated urban professional. Each speaker represents not a single point, but a span of this continuum. for he is usually able to adjust his speech upward or downward for some distance along it.(1961, p. 82)

The Creole continuum is not a fixed invariant system, but rather a porous, dynamic one. Indeed, linguists have usually pointed to the porosity of the continuum as a serious bartier to the use of Creole as an official language in any of the countries of the region; the main question being, which variety or point along the continuum should be selected, stabilized and used as the official language, and how to limit its merging with the standard language.

If Creole (i.e., a variety along the continuum) can be considered the mother-tongue of West Indians, the fact remains that it is an oral language ${ }^{4}$. English is the only language West Indians of every colour,

\footnotetext{
4The phonemic writing system developed for Jamaican Creole by Cassidy and LePage in their Dictionary of Jamaican English (1967) is used by linguists to represent other English-based Creoles in the Caribbean, but it has not been
} 
class or persuasion read and write. It is the language of the colonizer, but it is their otber-tongue - for it would be difficult to consider English a second language in the West Indies. However, neither the form nor the content of the English of the former Empire can fully express Caribbean experience and reality. West Indians have exploited the full creative potential of the English language, have forced the weight of their Caribbean culture and experience on it, have remoulded and recreated it into WIE, a hybridized English. The lexicon of WIE is the same as that of SE, with the inclusion of "WestIndianisms" grammar is practically the same as that of SE, with some variations ${ }^{6}$. The most obvious differences between SE and WIE are in pronunciation, intonation and accent (Ramchand, 1970, p. 93). If WIE (the acrolect) might be considered a variant of English, the mesolectal and basilect varieties of the continuum display such definite grammatical and lexical differences from SE that they cannot be considered English variants; they are definitely from another language system.

WIE speakers have been sufficiently educated to control the grammar and lexicon of SE; they may learn to pronounce differently but usually retain the ability to use their WI pronunciation; and above all, they are more or less instinctive speakers of and thinkers in a mesolectal variety or varieties of Creole (Ramchand, 1970, p. 94). The most distinctive speakers of WIE come from the Black or coloured (referred to as "creole") educated classes of WI society; these would have been the first groups to be indoctrinated by the colonial education system. WIE speakers have a wide linguistic range and WI writers, as speakers of WIE, are aIso speakers of Creole. However, Indo-Caribbean writers have a wider linguistic range than their Black or creole counterparts :

adopted by the general Creole-speaking public.

${ }^{5}$ E.g., words derived from English but no longer current in BE; words derived from non-standard British dialects; words derived from English but modified either in form or in function; words derived from other European languages, from African, from now-extinct Amerindian languages...

${ }^{6}$ E.g., repetition as marker of intensity; the verb "to be" is not required before certain adjectival complements; serial verbs are common; foregrounding of the verb for emphasis... 
they are primarily mesolectal speakers, educated enough to control the grammar and lexicon of SE (which makes them sound like WIE speakers), and coming from the rural areas, they have ready access to the basilect (that the older Indians still speak). In addition to their Creole range, Caribbean Indians also have access to Hindi, their pre-colonial language that is still alive (albeit creolized) in the villages. A summary of the Indo-Caribbean linguistic situation is represented in the following diagram.

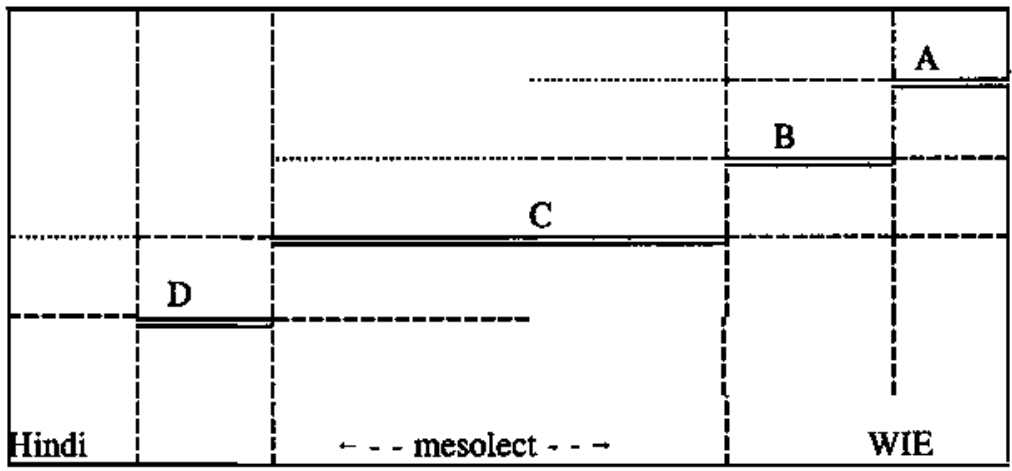
$A=$ SE speakers
$\mathrm{C}=$ Creole (mesolectal) speakers
B $=$ WIE (acrolectal) speakers
$\mathrm{D}=$ Creole (basilectal) speakers indicates competence

\section{Figure 2 : Indo-Caribbean Linguistic Range}

Hindi or Bhojpuri is still spoken, read and written as a first language by a dwindling number of Indians who live in the rural areas, where Hindu cultural and religious traditions are maintained. But the language is on its way to extinction since virtually all Caribbean Indians born after about 1920 speak Creole as their first language. The extent to which Hindi or Bhojpuri has influenced the syntax and phonology of the Creole spoken by Caribbean Indians has not been conclusively determined; however, the language certainly survives in the lexicon, as evidenced by the number of words having to do with culture, religion, kinship, food 
and rice-planting ${ }^{7}$, that the Indians developed parallel to the Britishowned sugar industry.

The histories of Trinidad and Guyana have produced interesting language situations. The island of Trinidad was initially colonized by the Spanish, settled by French-creoles from neighbouting islands, and finally established as a British colony in 1779 , with English becoming the official language in 1823. Trinidad gained independence from Britain in 1962, and became a Republic in 1976. In addition to the English-based Creole (Trinibagianese) spoken in Trinidad, which incorporates some Spanish and French lexicon, a French "patois" is still used in the mountains and rural areas. Guyana initially belonged to the Dutch, but by 1760 , it was mainly settled by the British. It came under British rule in 1814, and gained independence in 1966, becoming a Republic shortly afterwards, in 1970. Guyanese speak an English-based Creole (Guyanese Creole), however, a Dutch-based Creole (Berbice Dutch) is also spoken by a very small number of people in Corentyne, near the border with Surinam. Both Trinidad and Guyana have a $96 \%$ (English) literacy rate ${ }^{8}$.

\section{West-Indian and Indo-Caribbean Writing}

Street and Smith had made him think about the art of writing. Like many Trinidadians Ganesh could write correct English but it embarrassed him to talk anything but dialect except on very formal occasions. So while, with the encouragement of Street and Smith, he perfected his prose to a Victorian weightiness he continued to talk Trinidadian, much against his will.

(Naipaul, The Mystic Masseur, p. 71)

The imposition of English literacy in the Caribbean gave rise to an ambivalent relationship with language and contributed to distorting the cultural identity of the West Indian peoples. If West Indians are uncomfortable speaking English with other West Indians from a similar

1 E.g., barriat = groom's wedding party; jhandi = religious ceremony; aaji = paternal grandmother; curry-dhal and roti = curried lentils and Indian bread; shaii (rice) $=$ to sow.

* As per The Oxford Companion to the English Language. 
social class, they are also uncomfortable with the fact that Creole interferes when they (try to) speak English with non-West Indians or with West Indians from a higher social class. Speaking Creole marks them as being countrified and uneducated, speaking English makes them feel that they are putting on airs and imitating British mannerisms. Therefore, while speaking Creole serves, in a way, to unite the diverse ethnic elements in the Caribbean, English and English-language literature has always been the divisive factor in West Indian culture. Literature, in general, has an existence separate from its authors and a greater potential for more widespread influence. Orality, however, is more associated with a "face" or a personality. It is fragile and not easily preserved, it is modified from generation to generation, and it has limited influence outside its local area. Traditionally in the West Indies, literature, and specifically English literature, was more readily available to the educated middle- and upper-classes; orality was the culture of the lower agricultural and working classes, and it was mainly Creole in transmission - written English being just a classroom phenomenon. Some Indians also sent their children to Hindu schools, where they would learn to read and write Hindi, and become familiar with Hindu religious texts and other writings.

After the Second World War, in the pre-independence period, West Indian literature in English began to be seen as a rich and viable cultural vehicle for all classes of society. This literature was nonetheless produced and fostered, to a large extent, outside the West Indies by West Indians who had emigrated to Britain to take advantage of the economic prosperity of post-war Britain. Since the early 1950 s, almost all WI literature has been first published in England; some is now published in Canada, more specifically in Toronto, where there is a large West Indian population. While this body of literature very gradually received recognition in the West Indies and now enjoys stability and prestige as a national literature in WI education curricula, the fact that the bulk of it is written and published outside the West Indies has an impact on the language and texture of its production. WI writers are usually slotted under the category "writers of the post-colonial world" or "immigrant writers" in their host countries. As such, they are always "outsiders"; their literary production is always marginalized. WI writers, as primarily Creole speakers, do not have the same relationship to, nor do they use, the English language in the same way as maybe a monolingual Englishspeaker might : they must transform the language to accommodate their 
experience. WI texts constitute an intricately woven textile of the Creole and English languages, and of Creole and English narration traditions. This has a positively enriching effect on the writers' literary language and distinguishes their works from other literatures in English.

West Indian writings usually have a Caribbean setting and/or contain fictional characters and situations that are recognizably Caribbean in nature. As Ken Ramchand noted :

West Indian novelists apply themselves [...] to an analysis and interpretation of their society's ills, including the social and economic deprivation of the majority; the pervasive consciousness of race and colour; the cynicism and uncertainty of the [creole] bourgeoisie in power after independence; the lack of history to be proud of; and the absence of traditional and settled values.(1970, p.4)

Indo-Caribbean writings, however, constitute a literature in the making, characterized by the same preoccupations as their Creole counterpart, but with a shift in focus to encompass Indian and Hindu traditions, values and experience in the Caribbean. In Indo-Caribbean writings, the East Indian peasant is no longer another "coolie-from-the-country", but a real West Indian living in silence, joy and fear; participating in riots, Carnival and politics. East Indians are no longer peripheral, background or even nonexistent figures; they are the central characters, the main subject of IndoCaribbean writings.

The novels under consideration in this paper are the first novels of four Indo-Caribbean writers: Samuel Selvon (1923-1994) and V.S. Naipaul (b. 1932) from Trinidad; Arnold Itwaru (b. 1943) and Cyril Dabydeen (b. 1945), "maties" from Guyana. Selvon and Naipaul emigrated to England in the 1950s, prior to their country's independence from Britain and soon had their first novels published. Itwaru and Dabydeen immigrated to Canada in the early 1970 s, several years after Guyana's independence from Britain, and their first novels were published at the end of the $1980 \mathrm{~s}$, after they had completed their studies and established professional careers. There was no major novel production by the Indo-Caribbean community in the 1960s and 1970s; this missing generation can probably be accounted for by the identity crisis and struggle for survival that the transition from colonial to post-colonial society entailed. It is noteworthy that Selvon and Naipaul left Trinidad 
under the colonial regime, while Itwaru and Dabydeen experienced the racial, economic and political upheavals in post-colonial Guyana.

Samuel Selvon can be considered the forenunner of IndoCaribbean writing, not only for his thematic but also and more importantly for his use of Creole in his writing. As Ivan van Sertima has noted :

It was in $A$ Brighter Sun that an East Indian [Caribbean] writer himself spoke for the first time with quiet intimate authority and simple charm about the life of an Indian family in the Caribbean... Selvon's dialogue is more varied, and closer to the quick of the coloured proletarian and Indian peasantry, whereas Naipaul's has an urban sophistication and at times a somewhat impoverished, individual ring. (as quoted in Bernhardt, 1984, p. 266)

A Brighter Sun (1952) is set in Trinidad, and takes place from 1939 to 1945, when there was a constant American presence on the island. It narrates the life and relationships of Tiger, a young Indian peasant from a traditional Hindu background, thrust into manhood by the ubiquitous arranged marriage. Tiger and his wife leave the family enclave in the predominantly Indian village of Chaguanas, in the heart of the sugar-cane district, to set up house in Barataria, a racially-mixed rural community not far from the cosmopolitan capital, Port-of-Spain. The movement from an Indian to a racially-mixed village can be seen as a metaphor of the young man's move from the traditional close-knit Hindu lifestyle into creole society. Tiger's quest for knowledge is also a metaphor of a desire to broaden horizons, the only way to do so being through literacy.

V.S. Naipaul is probably the best-known Indo-Caribbean writer. The Mystic Masseur (1957), his first and probably most Caribbean novel, describes the rise from obscurity to fame of Ganesh Ramsumair, an unassuming countryboy, who possessed a large number of books, and who was therefore assumed to possess a great deal of knowledge. The novel spans the period from the beginning of the war to about 1953, and moves from Fuente Grove, a sad village at the far end of a sugar-cane area, not far from Princes Town, which is on the way to Port-of-Spain, the capital, a magnet for anyone with political aspirations. It describes Ganesh's career from failed schoolteacher to unqualified masseur to dubious mystic to MLC (Member of the Legislative Council), backed by 
the Hindu Association, to MBE, a title he seems to have acquired by chance. After finally "arriving" in colonial society of the day, he changes his name to G. Ramsay Muir, Esq. The novel portrays the country as the stronghold of Hindu spiritual and cultural traditions, and the city as the centre of politics and comuption. It is a satire on the rise to political fame in Trinidadian colonial society.

Cyril Dabydeen writes more poetry than prose, and has won a number of poetry awards in Guyana and Canada; he was the poet laureate of Ottawa from 1984 to 1987. His first novel, The Wizard Swami (1989) (first version published 1985 by The Writers' Workshop, Calcutta), was inspired by Naipaul's The Mystic Masseur and describes the drift of Devan, an awkward sugar-estate boy, who wants nothing from life but to be left alone to read the Vedas, practice yoga, pray and meditate. The story follows Devan's migration from bramchari in Providence on the Canje River, to swami in Mahaica (East Coast Demerara), a more raciallymixed village across the Berbice River, on the Atlantic, to Hindu schoolmaster in "a seedy, run-down area", a little way out of Georgetown, to trainer of Destiny, the racehorse of an executive member of the All India League in Georgetown, who is himself in the race to become president of the League. When Destiny behaves strangely before its big race, and the bewitched AIL executive loses the elections, Devan, the wizard swami, has visions of relinquishing life in the big city and returning to Providence. But everything has changed and the images seem to be slipping away.... It is basically a story of an Indian man awash in the tides of time, seeking his destiny in a fragmented society, a metaphor of the Guyanese Indian community seeking a place in a segregated, multiracial society.

Amold Itwaru is a poet, novelist and critic. He is the director of Caribbean Studies at New College, University of Toronto. Shanti (1988) is not a novel about peace. It is the story of a young Indian girl, a child of the plantation in colonial Guyana, where shame and suspicion, spearheaded by Reid, the Black sergeant detective of the district, surround her. When her childhood ends brutally in rape and the British overseer, who is known for having laid more than just a hand on the Indian women of the plantation, is found murdered, Shanti takes refuge in the home of the Indian schoolmaster. Her only hope of escaping from the cane-fields, he tells her, is through prayer and regular church attendance, and by 
studying diligently for the Pupil Teacher's Appointment exam. But Shanti will not surrender to colonial education : the British were dishonourable, they had pilfered from and violated her race, their teachings were blatant lies. She longs for the truth of the "backdam" silences, the music of "Indian Hour". Despite the odds, Shanti passes the exams with top marks, but her "uncooperative, subversive behaviour" prevents her from obtaining a position in any of the Mission schoois in the district. So while Latchman, her husband, is hired to promote education as the way to salvation, Shanti's "case" is held up as an example of learning gone wrong : a woman who sought to change her fate... The novel examines the deep animosity and hatred among Indians, Blacks and Whites in a plantation-based, colonial society, and explores the ruthlessness of male supremacy as a metaphor of imperialism.

\section{West Indian Writing as Translation}

As Octavio Paz remarked,

When we learn to speak, we are learning to translate; the child who asks his mother the meaning of a word is really asking her to translate the unfamiliar term into the simple words he already knows. In this sense, translation within the same language is not essentially different from translation between two tongues $[. .].(1992$, p. 152)

If WI writers learned to translate when they learned to speak, they certainly became aware of the need to translate when they learned to read and write English in the schoolrooms of the colonial education system. And translation within their oral Creole language-culture is quite different from translation between oral Creole and written English. Indeed, writing itself, as a form of translation or transmutation of meaning and experience into language, is a challenge to the WI writer, whose very meaning, experience and culture have been subjugated by the language in which it must be expressed.

Most WI writers live abroad, having immigrated for racial or economic reasons, and all WI literature in English is published outside of 
the West Indies'. Constantly writing in and for another culture, WI writers operate in a space between cultural and linguistic traditions : between Caribbean Creole culture and British or North American English culture, between the Creole language and the English language; between an oral genre (storytelling) and a written genre (novel or short story). WI writers are therefore faced with a number of challenges : as translators, they must master the language they write-translate from, as well as the language they write-translate into; as ambassadors, they must accurately re-present Caribbean experience and reality; as writers, they must communicate in a language that is accessible to as wide an audience as possible.

Operating from within a polydialectal Creole continuum, WI writers must assemble in their minds the entire overlapping array of language systems and sub-systems that constitute Creole, and create ways of reproducing them in an English-language text, so that the distinctions between the various systems are identifiable and meaningful to their audiences. WI literature negotiates between two audiences - an English audience and a Creole one - and must have the same or equivalent effect on both. WI writers must bear in mind that SE words shift in meaning in WI usage (e.g., "ignorant" means ill-tempered, uncontrolled), and that each variety of Creole is "loaded with crucial attitudinal, emotional, social and other semantic and semiotic messages" (D'Costa, 1983 , p. 255) : tone of voice, thythm of speech, intonation, register, culturally conditioned speech conventions are meaningful, as are gestures, facial expressions and other forms of body language. Indo-Caribbean writers must also, and primarily, account for their Indian heritage and Indo-Caribbean history and experience.

Operating from within a multicultural continuum - for the Creole continuum is also a socio-cultural one : the basilectal pole is to "primitive", working-class, oral culture what the acrolectal pole is to urbane, middle-class, anglicized culture -, WI writers must sift through the various cultural systems of the continuum and transpose them into an English-language text. Their task of communicating their Caribbean

\footnotetext{
9 There are no publishing houses in the West Indies. Small books, such as poetry collections, glossaries of Creole proverbs and expressions are published privately or by a government agency.
} 
culture in English is complicated by the fact that their competence within the continuum is likely to operate semantically and semiotically in different ways from those of speakers in other related language situations (e.g. diglossia) : they may not have mastered all the language varieties of the continuum, and therefore cannot access all the cultural varieties of the continuum. In addition, it is only Caribbean Indians who have access to Indian culture, no matter which part of the Creole language-culture continuum it crosses.

WI writers' medium of communication is written language, which places them in the sphere of the standard language - English -, and which provides the advantage of reaching a wide audience. However, in order to set themselves apart first and foremost from mainstream English literature writers, to satisfy themselves, their Creole-speaking audience and a wider international audience, WI writers must develop a literary language and a writing style that will meet the demands of acceptability within and without their own Creole-speaking community, and authenticity in the representation of the Caribbean language-culture. WI writers are often in a dilemma : if they opt for the semantic and semiotic patterns of the standard language-culture, they will lose the Creole-speaking audience (who want and need to see themselves represented), and if they stay with the Creole meanings, they will lose the international audience (D'Costa, 1983, p. 259). Selvon explained in an interview (Jussawalla and Dasenbrock, 1992, p. 104) that he always tried to keep "the essence, the music of the dialect", but in such a way that a non-Caribbean audience could follow the text. But he ran into criticism, with one of his earlier books, for writing "monkey smoke your pipe" in place of the typically Trinidadian expression crapaud smoke yuh pipe (meaning "things are bad"). His expression was considered a misrepresentation of the Creole. For his part, he felt that "monkey..." presented a visual image that had more universal appeal, yet would be recognizable by a Creole-speaking audience.

The degree to which WI writers "standardize" their literary language seems to be based on editorial and market pressures. Standardizing offers a picture-postcard but inaccurate representation of Caribbean language and culture, and further neutralizes the linguistic and cultural identity of the West Indian. But Jean D'Costa, a Jamaican who writes children's fiction explains: 
Each of my novels represents a separate set of literary and linguistic experiments in the communication of meaning. Each novel attempts to reach audiences both inside and outside of the [...] language continuum; the circumstances under which each was edited offered different challenges $[\ldots](1983$, p. 256$)$

She was able to make use of the entire range of the Creole continuum in one of her books published in 1976 :

based on the intention of publishers to market my books in the West Indies [...] only. It was then believed [...] that books like mine had no audience outside of Jamaica, and that even the migrant West Indian communities would reject my work on linguistic grounds. (1983, p. 260)

WI writers' choice of literary language is probably made easier by the fact that English is the only language West Indians read and write. Reading (or writing) a text in phonetics, even if it represents Creole speech, would jar both writer and reader, since literacy in Creole is never acquired. Readerresponse studies indicate that mother-tongue Creole speakers tend to back-translate into Creole when reading WI literature in English. This reaction is not merely back-translation, but a definite shift in perception and a culturally conditioned response : a statement like "'Arright, I goin' to mek him learn"' (The Wizard Swami, p. 11), is not grammatically correct in any of the varieties of the Creole continuum and must be considered an attempt to translate Creole into English. The speaker is an East Indian tailor in a village in Canje (Guyana), and he is making this ominous promise to an old East Indian labourer, direct from India, who wants his idle son to learn a trade. A Creole-speaking reader would most likely translate the statement back into the basilect, producing "Ah right, ah gun mek ee laarn" or "Ah right, ah gun laarn am good".

But the decision on how to use Creole, and how much to use, in their English-language texts is what determines the writing style of the WI writer, for whom style is the ultimate fulfilment of meaning potential, and a sure strategy for inscribing difference in the English language. The poeticity of WI writings lies in the hybridization of Creole and English : $\mathrm{SE}$ and/or WIE for the narrative, reported speech, expression of inner consciousness; and translated or "standardized" Creole for the dialogue sequences, which sometimes neutralizes the sociolinguistic distinctions 
between the characters. The use of Creole in WI literature in English might be considered "the esthetically intentional violation of the norm of the standard" (Mukarovsky, 1970, p. 42) making "possible the poetic utilization of language". But such an appreciation, if it comes from within the English literary institution, which judges and evaluates any literature in English in relation to the "Imperial Eye", negates the very intention of WI writers to differ from the language of their former colonizers. In order to stand on its own, WI literature must be considered a translation involving the poetic utilization of the predominantly oral Creole language-culture in English. WI writing as translation incorporates two aspects of the Creole language-culture : the storytelling genre or orality; and the Creole language itself.

\section{From Storytelling to Writing}

The model into which WI writers seek to transpose the oral aspects of their Caribbean language-culture continuum is the conventional 19th century English novel, taught to them in the schools. Creole sociolinguistic patterns are written into otherwise English novels (Caribbean setting, characters and bits of Creole aside), enabling the writers to achieve "certain stylistic effects not available to them within purely standard English narrative conventions" (O'Callaghan, 1984, p. 126), and to graft the Caribbean language-culture onto the English language-culture, thereby creating a linguistic and textual hybrid, in resistance to the imperial model.

WI literary culture is a relatively recent phenomenon; previously, artistic expression was almost exclusively within the oral tradition Caribbean folktales, known as Anancy stories, recounting the wily ways of the Anancy spider; East Indian folktales, recounting the adventures of animals in the jungle; folk songs; rhymes and riddles; chants; and so on. Oral language is dramatic - colourful, expressive and figurative; it relies on various devices to attract, maintain and generally direct the audience's attention, to counteract the impermanence of the spoken word and stimulate sensory, imaginative and emotional responses to the narrative. These devices include opening and closing formulae, repetition, detailed sensory descriptions, exaggeration, parataxis, direct address, interjections and onomatopoeia, tonal and rhythmic variations, and associative imagery. The writer wishing to capture the dramatic form of oral narration 
must transpose or find equivalences for at least some of these devices in the English-language text.

The repetition technique is used for various effects. In Shanti, repetition is used to remind the reader of the central theme of the story, the fateful impact of the ever-present sugar factory (a metaphor of the British presence) on the lives of the villagers :

The estate engines rose, shuddered, then snarled off into the distance... (p. 71) His voice rose, shuddered, snarled [...] (p. 72) The factory thrusted and pounded, puffed, and its afternoon siren screamed [...] (p. 74) The night tightened in the grinding snarl of the sugar factory [...] (p. 84) The factory puffed, snarled away, returned, and in the darkness of its thrust and pound [...] (p. 87)

While in $A$ Brighter Sun, repetition (and exaggeration) expresses continuous action :

Round, and round and round... He was drinking rum now. By the gallons. [...] He could see Tall Boy pouring it out, it poured amber. [...] The rum poured from huge barrels, but he couldn't get enough. He [...] opened the top of a barrel. Dark, mellow, cool, the rum looked to him. He had never seen so much rum at one time. He put his head down in it and drank. [...] He drank, drank, drank... (p. 153)

In The Mystic Masseur, repetition is used as an intensifier :

The boy look like a real, real smart man [...] (p. 16)

[...] you go write nice, nice books. (p. 54)

and to evoke an image of abundance and wealth in the detailed description of the masseur's hut :

There were books, books, here, there, and everywhere; books piled crazily on the table rising in mounds [...], books covering the floor. I had never before seen so many books in one place. [...] Four hundred Everyman, two hundred Penguin - six hundred. Six hundred, and one hundred Reader's Library, make seven hundred. I think with all the other book it have about fifteen hundred good book here. (p. 11)

Direct address is an oral narration device used to involve the audience in the story and to prevent their attention from wandering. It also serves to control the pace of the narrative : to build up suspense, or to give the 
listener time to assimilate the flow of events thus far. In The Mystic Masseur, the masseur's father-in-law-to-be tries to make him feel that he is already a part of the family and has a voice in business decisions :

'People can't harm me,' [...] I just go to San Fernando and open a little stall in the market. [...] Is exactly what I would do. Take a stall in the market. And what happen? Tell me, what happen?' (p. 42)

Interjections and onomatopoeia are not just oral narration devices but are a characteristic part of Caribbean language use. In The Wizard Swami, Devan, the swami :

bolted the door so no one could escape, took out his whip - as he recalled his teachers did to him at Providence Village - and lashed out : whop-whop-whop. (p. 72)

In Shanti, the "Kiss-kiss-ki-dee-ee!" (p. 45) of the kiskidee birds announces the dawning of a new day, while the invisible bird of the night calls "Who-you? Who-you?" (p. 82) in ghostly urgency and insistence. In Trinidad, where a French patois is still spoken in the rural areas, interjections are often in French. Thus, in A Brighter Sun, the creole woman in the village exclaims : "Eh bien! [...] All rite, me chile, Ah go take milk" (p. 35). And in The Mystic Masseur, Bissoon, the East Indian salesman, exclaims :

Tonnerre! But it hot today. You think you could give me just a sip of water? (p. 105)

Note here also the phrasing of the question, which depends on intonation as its marker.

The technique of associative imagery is used in Caribbean folktales and East Indian folktales : the traits of animal characters represent the traits of human beings, and the notion of time is expressed by the changes in nature. In Shanti, the image of an alligator attacking a hen at the edge of a roadside trench (p. 82) is used as a metaphor of Reid, the Black village policeman (the alligator), and Shanti, the young Indian girl (the hen). In A Brighter Sun, expressions of time are almost always accompanied or indicated by a description of nature at that time of the year : 
In April, when pouis blossomed and keskidees sang for rain, [...] (p. 3) In September much rain fell; it was the middle of the rainy season.(p. 3)

Mango season came. In the Northern Range the trees were in full fruit and schoolchildren on holiday roamed the hills [...] (p. 37)

In the dry season [...] (p. 18)

Or by recalling a national event or festival :

Trinidadians were allowed to indulge in two days of Carnival $[\ldots]$ (p. 210)

WI writers may also employ various speech conventions characteristic of Caribbean culture : code-switching, contrapuntal conversation, "big-talk," and "mouthing-off". In the Caribbean, a person's linguistic competence is dependent on social factors, which also determine his/her ability to codeswitch : "different social functions determine the lect, register or sub-code chosen for different communicative purposes" (O'Callaghan, 1984, p. 129). In A Brighter Sun, Tiger, the young Indian peasant, switches from the basilectal variety, which he uses with his wife, neighbours and other villagers, to an acrolectal approximation when conversing with his socially superior American bosses :

My humble abode is not a massive structure, [...] but I going to construct a building as soon as financial embarrassment is over. (p. 166)

But the unanticipated response of his boss causes him to slip back into Creole :

My wife could really cook good, [...] your mouth will nun water - I mean $-[. .$.$] your salivary glands will nun when you eat that food. (p.$ 167)

Code-switching as a device in WI writings is not merely to represent the linguistic phenomenon; switching codes or registers is also switching social roles, in order to be perceived differently.

Big-talk (boasting) and mouthing-off (insulting) are forms of self-assertion through language, usually associated with Black or coloured West Indians. Big-talking, often humorously outrageous in its claims, puts the big-talker beyond criticism and inadequacy by his fluency in using language, so much so that the big-talker can refute any challenge to his boast. Mouthing-off, which ranges from mild banter to public defamation, 
is striking out verbally before one can be attacked. The idea behind both being that the individual must put on a show of being mature and "hard", a veneer of bravado and aggression covering weakness or vulnerability (O'Callaghan, 1984, p. 130).

The contrapuntal nature of Caribbean interactions - the polyphonic, half-joking, half-serious and often cacophonic nature of most WI conversations and discussions - always leaves room for misinterpretation. The following passage from $A$ Brighter Sun is one of the best renderings of a typical communication situation in the Caribbean, complete with punning and tongue-in-cheek :

Sookdeo, an old Indian gardener in the village, who knew to read and write English perfectly, also made money by doing odd jobs with his donkey cart. But one rainy night Donkey fell ill and the next morning, refused to budge.

From that day Donkey wouldn't work anymore [...] and Sookdeo thought that the animal had gone blind.

A few days later Sookdeo decided to sell Donkey. Ramdhin, a young Indian, wanted a donkey cart to sell coconuts in Port of Spain. Sookdeo brought him home to see Donkey.

"Him fat, him doam plenty work and eatam little, but him don't 'look' well," Sookdeo said. [...]

"How yuh mean him don't look well?"

"Well, look dat side for yuhself, nar. Him don't 'look' well."

"He look plenty sick, if dat is wat yuh mean. I go give yuh fifty dollar. [...] And as Ramdhin was leading Donkey away [Sookdeo] called out, "Remember me tellam him don't 'look' well, but him work hard!" [...] The next morning just as he got his cutlass and hoe and was setting off for the fields Ramdhin came up.

Ramdhin was enraged, and for a minute he cursed Sookdeo steadily in Hindi. Then he broke out in broken English.

"But look here Sookdeo, wat yuh mean by selling me ah half-blind donkey?"

Sookdeo feigned astonishment. "But ine tellam him fat, him work hard, but him don't 'look' well."

Ramdhin choked. "But yuh is ah damn fool! Yuh can't even explain yuhself! Why yuh didn't tell me the donkey blind?"

"But me tellam! Me say him fat, but him don't 'look' well. Yuh don't understand when me talkam good English give yuh?" (pp. 71-72) 
Of all the Indo-Caribbean writers, Selvon is known for his ability to represent dialect variation throughout entire novels, "subtly intertwining dialectal complexities with the narrative" (Bemhardt, 1983, p. 266), and linguistic differentiation between Creole and English is most apparent in his novels. Most of his characters "command only the basilectal variety, for their circumstances are such that they only speak with others of equal status" (p. 268); they therefore have no need to shift toward the standard end of the continuum, and usually the reader must assume that they have not learned to do so (as with Sookdeo, the Indian gardener, above). Sometimes, Selvon's characters demonstrate an awareness of differences in social status and language use; however, they do not all have the ability to manipulate linguistic differences to their advantage (e.g. Tiger).

\section{From Creole into English}

Translation is a rewriting of an "original" text, and all "rewritings [...] reflect a certain ideology and a poetics and as such manipulate literature to function in a given society in a given way" (Bassnett and Lefevere in Venuti, 1995, p. vii). For WI writers, rewriting Creole into English is the only literary recourse available : it is the only language they write; it provides the advantage of reaching a wider audience; and it provides the opportunity to undermine the English with the very instrument of colonization. The textual hybridity obtained through rewriting Creole into English is necessary for the audibility and visibility of WI writers and their writings; it sets them apart from other writers of literatures in English and, perhaps more importantly, sets their work apart from mainstream English literature.

Translation is a process by which "the chain of signifiers that constitutes the source-language text is replaced by a chain of signifiers in the target language which the translator provides on the strength of an interpretation" (Venuti, 1995, p. 17); it is a process that involves writing. Since no two languages function in exactly the same way, translation inevitably involves substitution, replacement - and therefore, difference - of meaning. The translating language is always approximate, equivalent, never identical. At the lexical level, the translator (who is generally assumed to be translating into his own language) must choose from transcribing the foreign term (borrowing), translating it (free translation), substituting an equivalent sign (word/concept) from the target 
language-culture, naturalizing the foreign term with a loan translation (literal translation), adding/substituting a suffix from the target language to the foreign term, transcribing and defining the foreign term in the text or providing an out-of-text glossary, or in a push, paraphrasing the foreign term (Newmark, 1985).

In the novels looked at here, Hindi and Creole words are transcribed, sometimes defined in the text, sometimes accompanied by an out-of-text glossary, and this latter, usually at the editor's request. In Shanti, Kissoon, the Indian shopkeeper, swears at Reid, the Black police officer, calling him a "gaddaha bhoondoor" (p. 39), and as the fight in the rumshop moves into the street, one of the street fighters yells : "Dis is raas-pass!" (p. 88). In The Wizard Swami, Lachandai tells her husband that their son is no longer a child, "he is full-eye now" (p. 14), he should be married. On the day of the wedding, "the barriat, with his relatives (many of whom he didn't know existed) and a number of other male guests, took off for the bride's home [...]" (p. 16). In A Brighter Sun, the bride and groom exchange their marriage vows under "the purdah - the white sheet thrown over them -" (p. 7), while down by the Dry River, a big "bacchanal" (p. 25) - noise and confusion usually associated with fighting - is taking place. In The Mystic Masseur, the dowry exchange is a public event, "[...] the morning after the wedding the boy sit down and they give a plate of kedgeree, with the girl father having to give money and keep on giving until the boy eat [...]" (p. 46), and later on, that same "girl father" gets all nervous and agitated when he thinks that his son-inlaw is planning to "work magic and obeah" (p. 57) on him.

A free translation of WI terms is "hired taxis" (The Wizard Swami, p. 16) for "hire-car", which, in this context, simply means a car and its driver hired for a mission; and "mud-plaster" (The Mystic Masseur, p. 7) for "poultice", an English term given a particular meaning in WI usage : a poultice is always made of mud in the West Indies. The term "lower flat" (The Wizard Swami, p. 35) translates a reality simply referred to as "downstairs" or "a-bottom" in the Caribbean, and "thatched hut" (The Mystic Masseur, p. 34) has been substituted for "mud-hut", a house with a grass roof and mud walls.

If some terms have been transcribed or translated, others have been naturalized and transposed as is, for example, the term "hire-car" 
(Shanti, p. 57) which, in the context, is a car that usually does inter-city (towns or villages) trips for a set fare, and which takes in as many passengers (including their livestock) as it can hold. It is different from a "taxi", which can only be gotten at a stand or by telephone, the fare depending on distance travelled. Also transposed is the expression "bottom-houses", (The Wizard Swami, p. 22) which refers to the yard space below a house : in Guyana, houses in villages along the Atlantic coast or the shores of the rivers are built on pillars to protect them from flooding that can occur at high tide.

Some expressions are nonetheless untranslatable and must be paraphrased for an English speaker. One such expression is "suck teeth", also known as "schupsing". In fact, this is not so much an expression as it is the verbalization of an action instinctive to West Indians, and described (not very accurately) as "a loud clacking sound with [...] lips, teeth and tongue, pulled together and apart in an instinctive act" (The Wizard Swami, p. 13). This sound-act is considered rude and would often draw the admonition : "Don't suck yuh teeth at me!" or "Don't schups at me!"

Interference from the Creole is evidenced in the affixing of terms, such as "puzzle up" ( $A$ Brighter Sun, p. 159) for puzzled, "speechify" (p. 47) for making a speech, "clurkist" (The Mystic Masseur, p. 76) for clerk-typist ${ }^{10}$, and "massager" (p. 31) for masseur. Creole interference in English can also be detected at the syntactic level, especially in the dialogue sequences, with instances of transposition, modulation, calque, adaptation, expansion (Vinay and Darbelnet, 1975). "This time so, everybody know him for the smartest lawyer in town" ( $A$ Brighter Sun, p. 97) offers an example of transposition replacing "by now", and the synecdochic use of "foot" to mean "shin" in The Mystic Masseur (p. 7), "My foot was hot and swollen [...]", is a form of modulation often used by Creole-speakers, as is "hand" for "arm". Calque is also used in the translation of Creole in dialogue sequences : "But I go have to leave here now [...] It have a house there Ramgolan give me"'

\footnotetext{
${ }^{10}$ This has not been verified; it could be pure Naipaulian satire. But Trinidadians do pronounce "clerk" as "clurk" minus the ' $r$ ' sound, and not "claak" as Guyanese and British do.
} 
(The Mystic Masseur, p. 52); "'Let we say, you selling the book at two shillings, forty eight cents, [...] but - wait, man! I ain't even write the book yet"' (pp. 53-54); "'As long yuh_ain't wite, dey does call yuh black, wedder yuh coolie or nigger or chinee'"(A Brighter Sun, p. 95).

\section{Conclusion}

What I have attempted to show is that WI writing is translation, not just in the philosophical sense, whereby all writing could be considered translation, each text a translation of another text, but in the very concrete sense of the art and craft of rewriting in one language-culture what has already been established in another. The same techniques and strategies inevitably exploited by translators are used by WI writers, and indeed by all writers of the post-colonial world. Ashcroft, Griffiths and Tiffin (1989, pp. 61-77) describe "strategies of appropriation in post-colonial writing" in/through which difference or foreignness is constructed as including such "authorial intrusions" as in-text glossing, borrowing (transcribing), inter-language, syntactic fusion/variation, code-switching and vernacular transcription. These very same strategies are labelled as translation strategies above.

The WI writer "stands already in that position which will come to be occupied by an interpretation, for he/she is not the object of an interpretation, but the first interpreter" (p. 61).

WI writings are hybrid writings made possible through translation, itself made necessary through the legacy of colonization. The very textualization of WI experience is translation : "giving meaning to [WI] experience through the language of the imperial literary mode of expression, expressing [WI] experience in a context in which it exists as an alienated text; re-formulating [WI] experience to fit within the predetermined structural allowances of the genre in which it is written" (Itwaru, 1996, p. 2) is the translation of Creole experience into English. Yet today, "translation and writing are [...] perceived as the two terms of a binary opposition, in which the first - "translation" - is negatively marked, and the second - "writing" - is positively valorized" (StPierre, 1986, p. 223). This opposition between translation and writing parallels the continuum language situation from within which WI writers operate : the colonial myth that West Indians are native speakers of English, Creole being no more than a form of "broken English", another 
of the "unfortunate by-products of colonialism", has had the effect, even in the current post-colonial context, of negatively marking the Creole pole and positively valorizing the English pole.

Just as the distinction between Creole and English is blurred, so too is the distinction between translation and writing in WI writings. In fact, WI writings might be called self-translations - in the banal sense of translation of the self, but also in the sense of translation by the original writer. Since the writer has written the "translation", it seems to be considered "as somehow other than or less than a translation and to enjoy an authority that is in stark contrast to the dependency that translations normally suffer from in relation to their originals" (Fitch, 1986, p. 112). But in the case of WI writings, the "original" is not accessible in written form, only the translation is. WI writers' colonial history has made them masters of self-translation, for colonization created the need for them to be constantly involved in the process. Rather than re-place the translation of their Creole language-culture in the hands of an outsider, WI writers have appropriated mastery of the translation process, being as they are "in a better position to recapture the intentions of the author of the original than any other ordinary translator for the very good reason that those intentions [are], in fact, [their] very own" (p. 112). As self-translation, WI writing is set apart from other modes of translation by "the presence of the author as translator which gives to the translation an authority it would otherwise not have, which authorizes its substitution for the original [...]" (St-Pierre, 1986, p. 224), but which is, in fact, the original. The writing, the hybridized product of the self-translation, can be considered a true extract, a metaphor of the WI writer and his Creole language-culture.

Université de Montréal

\section{References}

\section{Novels}

DABYDEEN, Cyril (1988). The Wizard Swami, Leeds, Peepal Tree Press. ITWARU, Arnold (1990). Shanti, Toronto, Coach House Press. 
NAIPAUL, V.S. (1957). The Mystic Masseur, London, André Deutsch Ltd.

SELVON, Sam (1952). A Brighter Sun, London, Longman Group UK Ltd.

\section{Theory}

ASHCROFT, Bill, G. GRIFFITHS, H. TIFFIN (1989). The Empire Writes Back, London, Routledge.

BERNHARDT, S.A. (1983). "Dialect and Style Shifting in the Fiction of Samuel Selvon", CARRINGTON, L.D. (ed.) Studies in Caribbean Language, St. Augustine (Trinidad), Society for Caribbean Linguistics, pp. 266-276.

BIRBALSINGH, Frank (ed.) (1993). Indo-Caribbean Resistance, Toronto, TSAR Publications.

(ed.) (1996) Frontiers of Caribbean Literature in English, New York, St. Martin's Press.

D'COSTA, Jean (1983). "The West Indian Novelist and Language" in CARRINGTON, L.D. (ed.) Studies in Caribbean Language, St. Augustine (Trinidad), Society for Caribbean Linguistics, pp. 252-265.

DeCAMP, David (1961). "Social and Geographic Factors in Jamaican Dialects", LePAGE, R.B. (ed.) Creole Language Studies, London, Macmillan, pp. 61-84.

(1971). "Toward a Generative Analysis of a Post-Creole Speech Continuum", HYMES, D. (ed.) Pidginization and Creolization of Languages, Cambridge, Cambridge University Press, pp. 349-370.

DEVONISH, Hubert (1986). "The decay of neo-colonial official language policies", GÖRLACH, M. and J.A. HOLM (ed.) Focus on the Caribbean, Amsterdam/Philadelphia, John Benjamins, pp. 23-51. 
FITCH, Brian T. (1986). "The Status of Self-Translation", Texte, 4, pp. 111-125.

ITWARU, Arnold (1996). "Narration and the Imperialisation of Vision", Toronto, Unpublished Article.

JUSSAWALLA, F. and R.W. DASENBROCK (ed.) (1992). Interviews with Writers of the Post-Colonial World, Jackson, University Press of Mississippi.

MUKAROVSKY, Jan (1970). "Standard Language and Poetic Language", FREEDMAN, D.C. (ed.) Linguistics and Literary Style, New York, Holt, Rinehart and Winston, Inc., pp. 40-56.

NEWMARK, Peter (1982). Approaches to Translation, Oxford, Pergamon Press.

O'CALlAGHAN, Evelyn (1984). "Selected Creole Sociolinguistic Patterns in the West Indian Novel" in SMLLOWTZ, E.S. and R.Q. KNOWLES (ed.) Critical Issues in West Indian Literature, Parkersburg (IA), Caribbean Books, pp. 125-136.

The Oxford Companion to the English Language (1992), McARTHUR, T. (ed.), Oxford/Toronto, Oxford University Press.

PAZ, Octavio (1992). "Translation: Literature and Letters", SCHULTE, R. and J. BIGUENET (ed.) Theories of Translation, Chicago, The University of Chicago Press, pp. 152-162.

RAMCHAND, Ken (1970). The West Indian Novel and its Background, London, Faber and Faber.

RICKFORD, John (1987). Dimensions of a Creole Continuum, Stanford (CA), Stanford University Press.

ST-PIERRE, Paul (1986). "Translation and Writing", Texte, 4, pp. 223233. 
VENUTI, Lawrence (1995). The Translator's Invisibility, London, Routledge.

VINAY, J.P. and J. DARBELNET (1975). Stylistique comparée du français et de l'anglais, nouvelle édition, Montréal, Beauchemin.

RÉSUMÉ : Créole... anglais : l'écriture caribéenne comme traduction - Cet article examine les jeux de langues et langages dans la littérature indo-caribéenne de langue anglaise. Les écrivains caribéens sont créoles, dans tous les sens du terme : ils sont nés dans les (anciennes) colonies britanniques; ils appartiennent à une culture métisse; et ils parlent une langue métisse. Ils œuvrent dans un continuum linguistique et culturel créole; ils possèdent plusieurs variétés linguistiques (du créole à l'anglais standard) et revendiquent l'appartenance à plusieurs bases culturelles (de la culture orale "primitive" créole à la culture urbaine "anglicisée"). Toutefois, les écrivains indo-caribéens ont accès non seulement au continuum linguistique et culturel créole, mais aussi aux traditions culturelles, linguistiques et religieuses pré-coloniales de leurs ancêtres venus des Indes au XIX' siècle. Mais, si le créole est la langue maternelle des gens des Caraíbes, l'anglais n'en demeure pas moins la seule langue qu'ils.lisent et qu'ils écrivent. La littérature caribéenne de langue anglaise constitue un tissu soigneusement mé-tissé du créole et de l'anglais : une écriture métisse née de la traduction de l'expérience créole en anglais; de la culture orale créole en anglais écrit; et de la langue créole en langue anglaise. En fait, la litterature caribéenne de langue anglaise peut être considérée comme une auto-traduction, dont l'auteur-traducteur valide l'aspect métissé, un extrait authentique qui rend l'essence de l'écrivain caribéen et de sa langue-culture caribéenne.

\section{ABSTRACT : Creole... English: West Indian Writing as Translation}

- This paper looks at the use of language(s) in Indo-Caribbean (i.e., West Indian of East Indian descent) writings. West Indian writers are Creole, in every sense of the term: born in (former) British colonies, they have a hybrid culture and a hybrid language. They operate from within a polylectal Creole language-culture continuum which offers them a wide and varied linguistic range (Creole to Standard English) and an extended cultural base ("primitive" oral culture to anglicized written culture). IndoCaribbean writers, however, have access, not only to the Creole languageculture continuum, but also to the pre-colonial cultural, linguistic and 
religious traditions of their ancestors who came from India in the $19^{\text {th }}$ century. But if Creole is the mother-tongue of all West Indians, English is the only language they know to read and write. West Indian literature in English constitutes an intricately woven textile of Creole and English : a hybrid writing made possible through the translation of Creole experience into English; oral Creole culture into written English; the Creole language into the English language. In fact, West Indian literature in English can be considered self-translation, for which the presence of the author as the translator gives authority to the hybridized product, a true extract of the West Indian writer and his Caribbean language-culture.

Joanne Akai : Groupe de recherche en linguistique textuelle (GRELT), département de linguistique et de traduction, Université de Montréal, C.P. 6128, Succursale A, Montréal (Québec) H3C 3J7. 